\title{
The Impact of Work-related Stress on Job Satisfaction and Organizational Trust during COVID-19 Pandemic
}

\author{
Altanchimeg Zanabazar ${ }^{1, *}$, Sarantuya Jigjiddor $^{1}$, Tsolmon Jambal $^{2}$ \\ ${ }^{1}$ National University of Mongolia, Business School, Management department, Mongolia \\ ${ }^{2}$ Institute of Technology and Business, Faculty of Corporate Strategy, Okružní 517/10, 37001 České Budějovice, Czech Republic
}

\begin{abstract}
One of the industries significantly affected by the Covid-19 pandemic is tourism. As a result of lockdowns, tourism came to a halt, which has caused severe damages not only to tourism-related business but also aviation, hospitality sector, which resulted in unemployment, reduced work hours with minimum salary or temporary leave and even closure the businesses.

As a result of the pandemic, 99 travel agencies liquidated their business activities and the revenues of 88 percent of the whole tourism sector reduced and 56 percent of employees were laid off.

This paper analyses the impact of Work-related stress on the job satisfaction and organizational trust in the tourism sector during the unprecedented changes related to the Covid-19 pandemic. The survey was conducted online in April-May, 2021 and involved 275 employees working for different travel agencies. Numerous tests are used to verify the proposed hypothesis, such as factor analysis, reliability analysis, correlation analysis and PLS analysis.

The results of the survey show that the Work-related stress caused by Covid-19 pandemic has a negative impact on job satisfaction and organizational trust among surveyed employees.
\end{abstract}

Keywords: work-related stress; job satisfaction; organizational trust; COVID-19 pandemic

\section{Introduction}

The virus, first identified in Wuhan city, the People's Republic of China in December 2019, quickly spread around the world, was declared as a pandemic by the World Health Organization in March 2020 [1]. [2].

According to World Travel and Tourism Council, more than 50 million jobs are at risk due to the emerging situation

The National Security Council of Mongolia issued Directive No. 01/01 "Temporary border shutdown" on January 30, 2020 and introduced lockdown on February 01, 2020. The measures taken by the government made the businesses completely suspend their activities. This applied also to businesses operating in tourism and hospitality sectors. Many of them were even forced to file for bankruptcy as well as well as laying off their employees [3].

The study conducted by Mongolian Chamber of Commerce and Industry shows that 90 percent of businesses in tourism sector have been affected by those unprecedented circumstances [4]. As a result, employee well-being is threatened significantly due to loss of income affecting their lifestyle, standard and quality of living and mental health conditions.

Numerous studies have been conducted among health professionals to evaluate the impact of the pandemic related to job stress, depression, anxiety and insomnia; however, there are not many studies addressing the level of employee fear, irritation and stress, and depression related to uncertainty among the employees in tourism and hospitality sector [5-6].

Tourism is definitely one of the sectors seriously affected by the Covid-19 pandemic. Due to the pandemic, 99 travel agencies suspended or closed down their business, 88 percent of them faced a 91-100\% income shortage and 56 percent of them reduced the number of their employees [7].

This study is aimed at analysing employee Work-related stress and job satisfaction of local tourism travel agencies' employees and their impact on the organizational trust.

\section{Job stress and Job Satisfaction}

Lazarus and Folkman describe stress as a physiological response to a potential threat to human well-being. It is a physical and mental reaction to the changes that people face in their daily life or needs that come up in life. Job stress is characterized by discrepancies between the demand of workplace and personal skills of the person who strives to meet

\footnotetext{
* Corresponding author: altanchimegz@num.edu.mn
} 
the needs [8-9]. On the other hand, job satisfaction also plays an essential role in preventing and handling employee stress [10].

When people feel and perceive less support or cooperation from their co-workers and managers, it can lead to stress, which negatively contributes to the loss of self-confidence, decrease in job satisfaction and performance [11-12]. Many studies have been conducted to identify possible negative impacts of Work-related stress on employee work teams as well as organization as such. Work-related stress.

Recently, a new term appeared - pandemic stress originating from the spread of Covid-19. People are now spending a significant portion of their daily life working online due to lockdowns introduced and have easier access to large quantities of information on the pandemic, and their increased fear over uncertainty of their employment and stability of the future income often leads to stress and depression [13].

One of the crucial factors in achieving organizational objectives is employee job satisfaction [14]. Employee job satistifaction refers to the employee attitude to their job or subjective experience gained throughout their professional life [15].

According to Herzberg, performance outcomes is a source of both job satisfaction or dissatisfaction that occur due to certain workplace circumstances and hygiene factors. The issue of job satisfaction needs to be addressed as it is closely related to numerous organizational problem such as absenteeism, staff turnover, commitment and productivity [16].

Many researchers have confirmed the negative impact of Work-related stress on mental health and decrease in employee job satisfaction [10, 17-19].

During the Covid-19 pandemic, job security is a main stress-inducing factor, which leads to a decrease in job satisfaction and contributes to mental health concerns [20].

\section{Work-related stress and Organizational trust}

In the present, business success is heavily dependent on the organizational trust, even more than it used to be. Trust plays a crucial role in interpersonal communication and collaboration. Trust is considered as a success factor for any organization and its management since zero trust in the organization hinders maintaining open and sincere communication between managers and employees, which often leads to mistrust [21].

Organizational trust is an essential factor maintaining communication and collaboration among the employees of the organization and demonstrates the individuals' expectations regarding organizational communication and behaviour [22]. In simple terms, organizational trust shows employee expectations and trust concerning the belief in the organizational activities as well as its employees. Employees who show high levels of trust in the organizational management and coworkers tend to be more loyal.

Studies show that employees who suffer from stress often lose trust in organizational commitment and job security [23-24]. Job related stress reduces organizational trust and directly or indirectly affects staff turnover [25].

\section{Job Satisfaction and Organizational Trust}

Job satisfaction and organizational trust are factors that contribute to achieving the goals of a given organization and gain a competitive advantage over competitors. Organizational trust brings various positive effects both for employees and the organization. Higher level of organizational trust among its employees increases employee loyalty to the organization and higher employee job satisfaction [26].

There is a positive correlation between organizational trust and job satisfaction; high level of organizational trust results in high level of employee job satisfaction [27-29].

Research design: Based on literature review, the following research model is proposed to achieve the objectives of the study: 


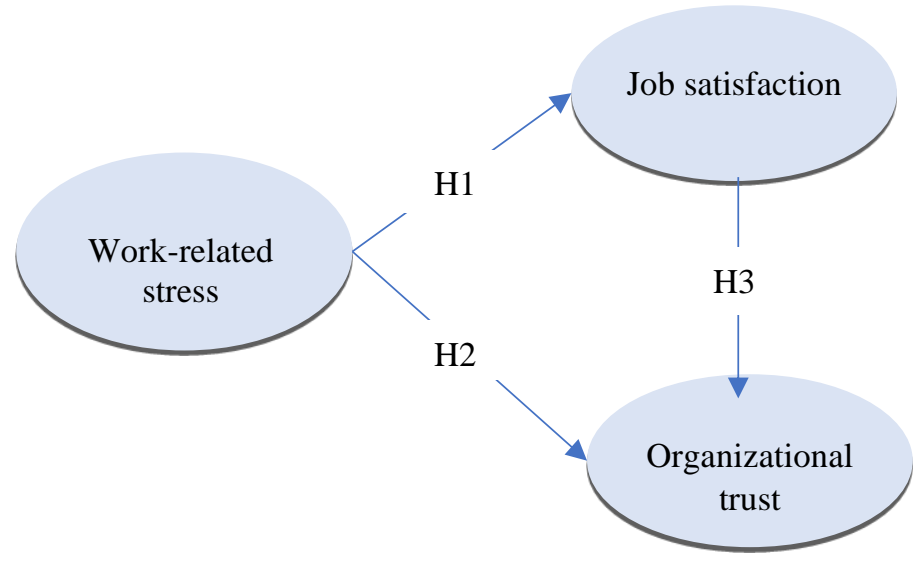

H1: Work-related stress influences has a negative impact on employee job satisfaction.

H2: Job stress negatively affects the organizational trust.

H3: Job satisfaction influences the organizational trust.

Figure 1. Word cloud of publication keywords on the topic of employee engagement

Source: Author.

\section{Methodology}

The objective of the study is to investigate the impact of Work-related stress on employee job satisfaction and organizational trust in the tourism sector in the wake of the unprecedented changes caused by the Covid-19 pandemic.

A total of fifteen travel agencies participated in the survey. SPSS 23.0 and Smart PLS 3.0 software, which are widely used in the social sciences research, are used for the data analysis. Numerous tests are performed to confirm or reject the formulated hypothesis, such as factor analysis, reliability test and regression analysis.

\section{Data collection and data source}

When selecting the sample, $95 \%$ confidence level with $5 \%$ confidence interval was considered. There were selected 275 out the total of 618 employees working in 15 travel agencies. We used the data of 275 participants, which is a sufficiently representative sample. The survey was conducted online between April 12 and May 20, 2020. The survey questionnaire consisted of 18 questions related to organizational trust, job satisfaction and stress; each question was rated on a 5-point Likert scale. In the study, the changes in demographic factors including age, sex, marital status, education, salary and employment status were considered.

Table 1. Background information on the Respondents

\begin{tabular}{|l|c|c|l|c|c|l|c|c|c|}
\hline \multicolumn{3}{|c|}{ Age } & \multicolumn{3}{c|}{$\begin{array}{c}\text { Length of employment in the } \\
\text { company }\end{array}$} & \multicolumn{3}{c|}{ Changes in employment } \\
\hline & n & $\%$ & & n & $\%$ & & n & $\%$ \\
\hline $20-25$ & 16 & 5.9 & Up to 1 & 32 & 11.6 & Paid holiday & 13 & 4.7 \\
\hline $26-30$ & 78 & 28.3 & $1-3$ years & 144 & 52.4 & Decrease in worked hours & 80 & 29.1 \\
\hline $31-35$ & 73 & 26.5 & $4-10$ years & 51 & 18.5 & No salary & 114 & 41.5 \\
\hline $36-40$ & 80 & 29.1 & $11-15$ years & 36 & 13.2 & Lost job & 68 & 24.7 \\
\hline $41-50$ & 22 & 8.1 & 16 years and more & 12 & 4.3 & No change & - & - \\
\hline 51 and older & 6 & 2.1 & & & & & & \\
\hline
\end{tabular}

Source: Author.

Of the 275 participants, $58.9 \%$ were female and $41.1 \%$ male; as for age, they were relatively young employees at their twenties - fourtiesged 20-40's (89.8\%). The majority of the participants (64\%) worked 1-3 years for their organization; $18.5 \%$ of them worked in the sector for 4-10 years, and remaining $17.5 \%$ of them for more than 16 years. The results show that in terms of the pandemic-related consequences, $24.7 \%$ of the participants experienced unemployment, $41.5 \%$ unpaid leave, $29.1 \%$ reduced working hours, and only $4.7 \%$ had a paid leave. This indicates that employees in the tourism and hospitality sectors have faced the biggest risks associated with loss of income and loss of job. 


\section{Reliability analysis of variable}

Cronbach $\alpha$ test is performed to test the reliability of the questionnaire. The test showed a value greater than 0.7 [30] and was thus evaluated as capable of measuring the proposed variables. Moreover, Composite Reliability coefficient showed a value of 0.5 [31]; the questions included in the questionnaire are reliable for the purposes of the study. Reliability test results are summarized in Table 2 below.

Table 2. Questionnaire reliability analysis

\begin{tabular}{|l|c|c|c|c|}
\hline \multicolumn{1}{|c|}{ Set of items } & $\begin{array}{c}\text { Number of } \\
\text { questions }\end{array}$ & Cronbach's $\boldsymbol{\alpha}$ & AVE & CR \\
\hline Work-related stress - WS & 6 & .892 & .630 & .910 \\
\hline Job Satisfaction - JS & 6 & .913 & .679 & .927 \\
\hline Organizational trust - OT & 6 & .869 & .597 & .899 \\
\hline
\end{tabular}

Source: Author.

\section{Correlation analysis}

To estimate the correlations of the factors' correlations, Pearson Correlation analysis is carried out and the results are summarized in Table 3.

Table 3. Pearson Correlation analysis

\begin{tabular}{|l|l|r|r|r|}
\hline \multicolumn{5}{|c|}{ Correlations } \\
\hline \multirow{2}{*}{ WS } & \multicolumn{1}{|c|}{ WS } & \multicolumn{1}{c|}{ JS } & OT \\
\hline \multirow{2}{*}{ JS } & Pearson Correlation & 1 & & \\
\cline { 2 - 5 } & Sig. (2-tailed) & & & \\
\hline \multirow{2}{*}{ OT } & Pearson Correlation & $-.580^{* *}$ & 1 & \\
\cline { 2 - 5 } & Sig. (2-tailed) & .000 & & \\
\hline \multirow{2}{*}{$* *$ Correlation is significant at the 0.01 level (2-tailed). } \\
\cline { 2 - 6 } & Pearson Correlation & $-.655^{* *}$ & $.593^{* *}$ & \\
\hline
\end{tabular}

Source: Author.

The results of the analysis indicate notable negative correlations [r=-.580, $\mathrm{p}<0.01]$ of work-related stress, job satisfaction and organizational trust in the case of the surveyed participants show Job satisfaction and organizational trust among the participants show significant positive correlations [r=593, $\mathrm{p}<0.01]$.

\section{Structural equation modelling}

To ensure the reliability of the survey data and evaluate the survey model, R-Square is estimated. We used PLS analysis to measure the proposed model's predictive power. Factors related to the independent and dependent variables are carefully checked step by step. The results of the analysis show that all hypothesis formulated for the purposes of the study can be confirmed; regression analysis show a significant $\mathrm{p}$-value $(\mathrm{p}<0.05)$. The results of the analysis are summarized in Table 4.

Table 4. Research result PLS-SEM

\begin{tabular}{|c|l|c|c|c|c|}
\hline Hypothesis & \multicolumn{1}{|c|}{ Path } & $\begin{array}{c}\text { Standardized } \\
\text { Beta }\end{array}$ & t value & P value & Remarks \\
\hline H1 & WS $\rightarrow$ JS & -0.492 & 6.492 & .000 & Supported \\
\hline H2 & WS $\rightarrow$ OT & -0.610 & 7.459 & .000 & Supported \\
\hline H5 & JS $\rightarrow$ OT & 0.330 & 5.779 & .000 & Supported \\
\hline
\end{tabular}

Source: Author.

According to the results, participants' work stress of participants impacted slightly on job satisfaction[ $\beta=-0.492]$ while it strongly affected to the organizational trust $[\beta=-0.610 ; p<0.01]$. Job satisfaction has a moderate impact on organizational trust $\beta=0.330 ; p<0.01]$. Normative estimate is presented in below Figure 1 . 


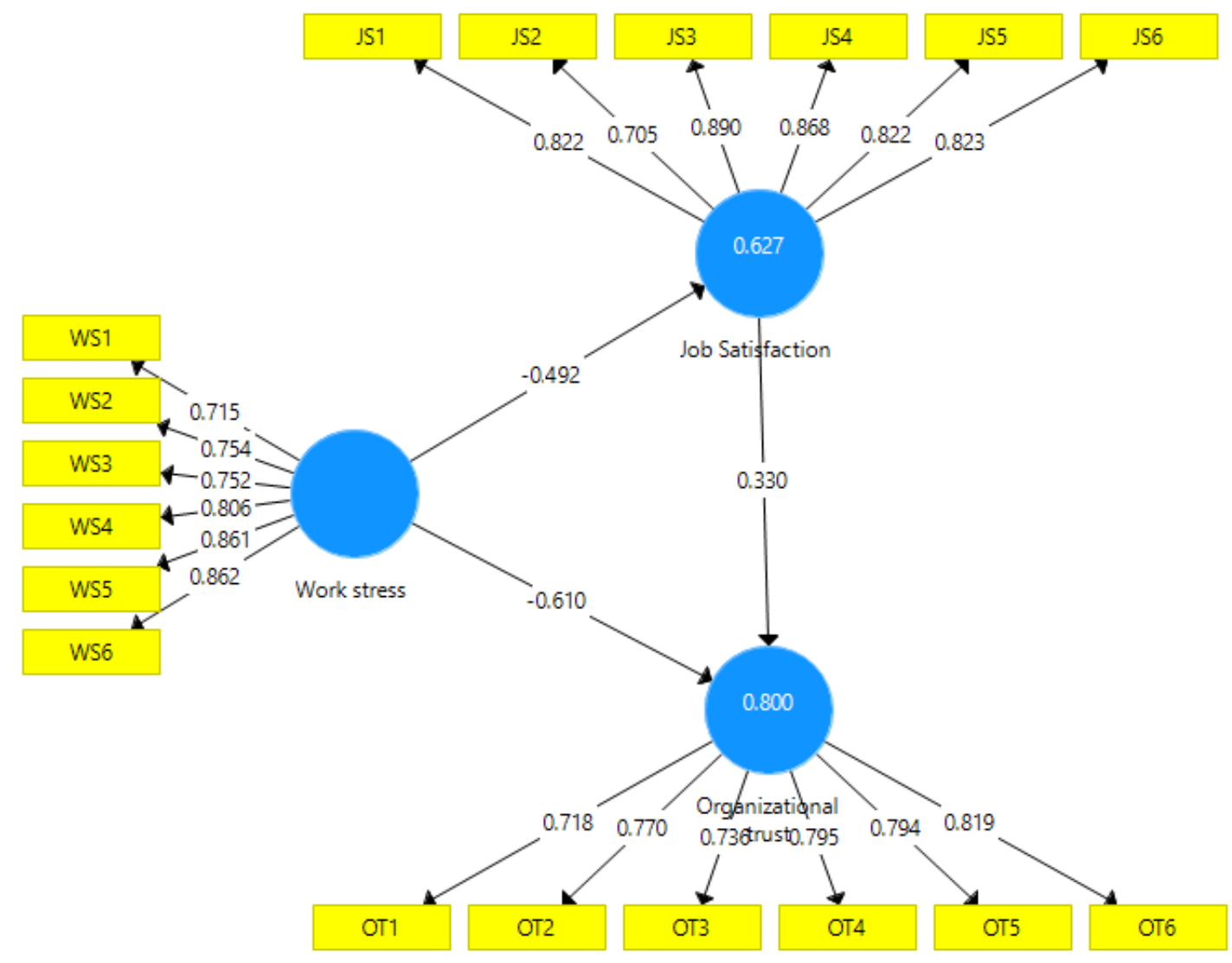

Figure 2. Path Model and PLS-SEM Estimate

Source: Author.

The effects of all moderating variables turned out to be positive (Beta coefficient) and statistically significant (p $<0.05)$. It can thus be concluded that the hypotheses formulated are valid.

\section{Conclusion}

The uncertainty arising from the pandemic is the main factor that causes the stress of employees. High stress level affects productivity, reduces employee job satisfaction and organizational trust, which may result in the failure of the entire organization [32]. Therefore, organizations need to tackle the problem through identifying employee stress level, its causes and finding solutions to resolve the situations [17].

In the case of tourism and hospitality sectors, employees have faced numerous challenges including job security, layoffs, income decrease, work break, work and life balance and livelihood, which are the main sources of stress reducing employee job satisfaction as well as organizational trust.

The objective of the paper was to investigate the impact of work-related stress on employee job satisfaction and organizational trust in the case of travel agencies in the wake of unprecedented changes caused by the pandemic.

According to the results of the study, work-related stress can be a significant factor reducing job satisfaction and organizational trust. The results of the survey are consistent with the results of earlier studies conducted in the area, such as research by Feather \& Rauter [24], Bhatti \& et al. [17], Chao \& et al. [18], Hoboubi \& et al. [10], Hsu \& et al. [19], and Said \& El-Shafei [25].

The results show that an increase in work-related stress by one unit results in a decrease in job satisfaction by 0.492 (Beta) unit and a decrease in the organizational trust by 0.610 (Beta) unit.

Moreover, job satisfaction has a significant impact on organizational trust among employees. Organizational trust is a psychological commitment of the employee to the organization by accepting its philosophy and confidence in its' future that is nurtured overtime.

An increase in job satisfaction by one unit results in an increase in organizational trust by 0.330 (Beta) unit, means higher job satisfaction level tend to make employees be loyal and trust their organization, which make them deepen their commitment and show positive attitudes towards the organization. 
The results were also consistent with the previously conducted studies by numerous researchers, such as Perry \& Mankin [27], Fard \& Karimi [28], Artar \& Erdil [29] and Aygün [26].

It can thus be concluded that there is a positive correlation between organizational trust and job satisfaction, which means that in organizations where the trust level remains high employees show higher job satisfaction.

As we decided to conduct the current survey due to the increasing public discussion on ambiguity of the tourism sector, we have no possibility to compare the previous state of work-related stress level and its impact on organizational trust. Further research could focus on comparing the changes in work-related stress.

Therefore, it is essential for any organization to deal with work-related stress and take preventive measures reducing the negative impacts that may result from the stress and other negative job practices to maintain healthy work environment where employees tend to remain loyal and positive towards not only to their jobs but also to their organizations.

\section{References}

1. World Health Organization. WHO director-General's opening remarks at the media briefing on COVID19 [online]. Available at: https://www.who.int/dg/speeches/detail/who-director-general-s-opening-remarks-at-the-mediabriefing-on-covid-19---11-march-2020 (2020)

2. World Travel \& Tourism Council. Coronavirus Puts Up to 50 Million Travel and Tourism Jobs at Risk Says WTTC [online]. Available at: https://wttc.org/News-Article/Coronavirus-puts-up-to-50-million-Travel-and-Tourism-jobsat-risk-says-WTTC (2020)

3. L. Sarangerel et al. COVID-19 Impact on small businesses. Ulaanbaatar: Edmarket. (2020)

4. MNCCI. Research report of employment impact of Covid-19. Ulaanbaatar: Mongolian National Chamber of Commerce and Industry. (2020)

5. J. Lai, S. Ma, Y. Wang, et al. Factors Associated With Mental Health Outcomes Among Health Care Workers Exposed to Coronavirus Disease 2019. JAMA Network Open. 3(3):e203976, 1-12. doi:org/10.1001/jamanetworkopen.2020.3976 (2020)

6. S. Pappa, V. Ntella, T. Giannakas, V. G. Giannakoulis, E. Papoutsi, P. Katsaounou (2020). Prevalence of depression, anxiety, and insomnia among healthcare workers during the COVID-19 pandemic: A systematic review and metaanalysis. Brain, Behavior, and Immunity. 88, 901-907 doi:org/10.1016/j.bbi.2020.05.026 (2020)

7. Y. Badyelgaji. Covid-induced challenging losses to a national economy of East Asia: The 2020 economic case of the tourism sector in the Ulaanbaatar area of Mongolia. Ulaanbaatar: Mongolian National University (2020)

8. T. W. Colligan, E. M. Higgins. Workplace stress: Etiology and consequences. Journal of Workplace Behavioral Health. 21(2), 89-97. doi:org/10.1300/J490v21n02_07 (2006)

9. M. Beheshtifar, R. Nazarian, Role of occupational stress in organizations. Interdiscıplinary, Journal of Contemporary Research in Business. 4(9), 648-658 (2013)

10. N. Hoboubi, A. Choobineh, F. K. Ghanavati, S. Keshavarzi, A. A. Hosseini. The Impact of Work-related stress and Job Satisfaction on Workforce Productivity in an Iranian Petrochemical Industry. Safety and Health at Work. 8(1), 67-71. doi:org/10.1016/j.shaw.2016.07.002 (2017)

11. A. Y. Poor, E. M. Ahmed. F. M. Ansari, M. Movahedi. Investigating the relationship between Work-related stress and organizational trust in Sirjan Municipality. World Applied Sciences Journal. 32(10), 2042-2047 (2014)

12. H. C. Yang, Y. H. Ju, Y. C. Lee, Y. C. Effects of Work-related stress on self-esteem, job satisfaction, and turnover intention. Journal of Transnational Management. 21(1), 29-39. doi:org/10.1080/15475778.2016.1120613 (2016)

13. A. R. Ahmad, H. R. Murad. The Impact of Social Media on Panic During the COVID-19 Pandemic in Iraqi Kurdistan: Online Questionnaire Study. The Journal of Medical Internet Research. 22(5) doi:org/10.2196/19556 (2020)

14. M. L. Azic. The Impact of Hotel Employee Satisfaction on Hospitability Performance. Journal of Tourism and Hospitality Management. 23(1), 105-117 (2017)

15. M. Miembazi, Y. Qian. Research on the impact of organizational commitment on job satisfaction between China and Congo-Brazzaville. Journal of Research in Business, Economics and Management. 8(3), 1444-1450 (2017)

16. R. Kreitner, A. Kinicki, A. Organizational behavior. Boston: Irwin/McGraw-Hill (2001)

17. N. Bhatti, M. A. Hashmi, S. A. Raza, F. M. Shaikh, K. Shafique. Empirical Analysis of Work-related stress on Job Satisfaction among University Teachers in Pakistan. International Business Research. 4(3), 264-270 (2011) 
18. M.-C. Chao, R.-CH. Jou, C.-Ch. Liao. Workplace Stress, Job Satisfaction, Job Performance, and Turnover Intention of Health Care Workers in Rural Taiwan. Asia-Pacific Journal of Public Health. 27(2), 1827-1836 doi:org/10.1177/1010539513506604 (2015)

19. Y.-Y. Hsu, Ch.-H. Bai, Ch.-M. Yang, Y.-CH. Huang, T.-T. Lin, Ch.-H. Lin. Long Hours' Effects on Work-Life Balance and Satisfaction. BioMed Research International. 2019(1), 1-8. doi:org/10.1155/2019/5046934 (2019)

20. T. Nyanga, A. Chindanya. Covid 19 Pandemic Shifting The Job Satisfaction Landscape Among Employees. Business Excellence and Management, Faculty of Management, Academy of Economic Studies, Bucharest, Romania. 10(5), 168-176 (2020)

21. E. M. Ahmed, A. Y. Poor, F. M. Ansari, M. Movahedi. Investigating the Relationship Between Work-related stress and Organizational Trust in Sirjan Municipality. World Applied Sciences Journal. 32(10), 2042-2047 (2014)

22. P. S. Shockley-Zalabak, S. Morreale, M. Hackman. Building the high trust organization: Strategies for supporting five key dimensions of trust. San Francisco, CA: Jossey-Bass (2010)

23. M. Sverke, J. Hellgren, K. Näswall. No security: A meta-analysis and review of job insecurity and its consequences. Journal of Occupational Health Psychology. 7(3), 242-264 doi:org/10.1037/1076-8998.7.3.242 (2002)

24. N. T. Feather, K. A. Rauter. Organizational citizenship behaviors in relation to job status, job insecurity, organizational commitment and identification, job satisfaction and work values. Journal of Occupational Psychology. 77(1), 81-94 doi:org/10.1348/096317904322915928 (2004)

25. R. M. Said, D. A. El-Shafei. Occupational stress, job satisfaction, and intent to leave: nurses working on front lines during COVID-19 pandemic in Zagazig City, Egypt. Environmental Science and Pollution Research. 28, 87918801 doi:org/10.1007/s11356-020-11235-8 (2021)

26. M. Aygün. Analysis of the relationship between job satisfaction and organizational trust of physical education and sports teachers. Journal of Pedagogical Research. 5(1), 203-215 doi:org/10.33902/JPR.2021167583 (2021)

27. R. W. Perry, L. D. Mankin. Organizational Trust, Trust in the Chief Executive and Work Satisfaction. Public Personnel Management. 36(2), 165-179 doi:org/10.1177/009102600703600205 (2007)

28. P. G. Fard, F. Karimi. The Relationship between Organizational Trust and Organizational Silence with Job Satisfaction and Organizational Commitment of the Employees of University. International Education Studies. 8(11), 219-227 doi:org/10.5539/ies.v8n11p219 (2015)

29. M. Artar, O. Erdil. Relationship Between Job Satisfaction, Organizational Trust And Work Alienation. 13th International Strategic Management Conference, The European Proceedings of Social \& Behavioural Sciences. 194-205 doi:org/10.15405/epsbs.2017.12.02.17 (2017)

30. J. Nunnally. Authors should use the forms shown in Table 3 in the final reference list. New York: McGraw-Hil (1978)

31. J. Hair, W. Black, B. Babin, R. Anderson, R. Tatham. Multivariate Data Analysis (6th ed.). Upper Saddle River, NJ: Pearson Prentice Hall (2006)

32. S. H. Haynes, M. C. Leone, L. D. Keena, D. C. May, R. Ricciardelli, E. G. Lambert. The association between different forms of organizational trust and correctional staff job stress. Journal of Crime and Justice. 43(5), 623-639 doi:org/10.1080/0735648X.2020.1734056 (2020) 